( $)$ The Author(s) 2016. This is an Open Access article, distributed under the terms of the Creative Commons Attribution licence (http://creativecommons. org/licenses/by/4.0/), which permits unrestricted re-use, distribution, and reproduction in any medium, provided the original work is properly cited.

\title{
Variations in atmospheric dust loading since AD 1951 recorded in an ice core from the northern Tibetan Plateau
}

\author{
Wangbin ZHANG, Shugui HOU, Wenling AN, Liya ZHOU, Hongxi PANG \\ Ministry of Education Key Laboratory for Coast and Island Development, School of Geographic and Oceanographic Sciences, \\ Nanjing University, Nanjing, China \\ Correspondence: Shugui Hou <shugui@nju.edu.cn>
}

\begin{abstract}
An ice core was extracted from the Zangser Kangri (ZK) ice field in the northern Tibetan Plateau (NTP), a location with limited instrumental and proxy records. In this paper, we present a continuous high-resolution dust concentration time series spanning the period AD 1951-2008 to investigate variations in atmospheric dust loading over the NTP. The results show that atmospheric dust loading exhibited significant decadal variations, with two periods of high dust loading (AD 1959-67 and AD 1979-89) and three periods of relatively low loading (AD 1951-58, AD 1968-78 and AD 1990-2008). The variability of atmospheric dust loading was related to wind speed at $500 \mathrm{hPa}$ over the dust source regions. The winter Arctic Oscillation (AO) index showed a significant negative correlation with the annual dust concentration, implying a possible connection between the winter $\mathrm{AO}$ and the atmospheric dust loading over the NTP.
\end{abstract}

KEYWORDS: ice core

\section{INTRODUCTION}

As one of the most abundant types of aerosol in the atmosphere, dust has recently received considerable attention due to its role in the climate system, global biogeochemical cycles, hydrologic cycles, air quality and public health (Yumimoto and others, 2010). Many observational studies have shown that dust can reflect sunlight and cool the climate (Haywood and Boucher, 2000; Slingo and others, 2006). Dust can also modify cloud properties and the formation of precipitation (Rosenfeld and Farbstein, 1992). In addition, if densely populated cities are on main dust transport paths, then it can be a serious natural hazard to human society. Therefore, the reconstruction of past atmospheric dust concentrations is important in understanding the climate and environmental conditions.

Ice-core records provide the most direct and detailed way of investigating temporal variations in regional atmospheric dust. Central Asia, the second largest dust source region in the Northern Hemisphere, is an ideal location for the retrieval of ice cores because it contains several of the Earth's highest mountain ranges (e.g. Himalaya, Pamir, Hindu Kush, Kunlun, Tien Shan and Altai) and the Tibetan Plateau (TP), which spans $\sim 2.5 \times 10^{6} \mathrm{~km}^{2}$, with an average elevation of $\sim 4000 \mathrm{~m}$. Over the past few decades, many studies have reported dust concentrations in the ice cores retrieved from the TP, including such locations as Puruogangri (Thompson and others, 2006), Geladaindong (Wake and Mayewski, 1994), East Rongbuk (Xu and others, 2007), Tanggula (Wu and others, 2013), Chongce (Han and others, 2006) and Guliya (Thompson and others, 1997). These studies provide high-resolution climate records that have added greatly to the understanding of the Asian climate.

The northern Tibetan Plateau (NTP) is an arid/semi-arid region in part because of the high surrounding mountains and the large distance from the coast (Dong and others, 2010). The Himalaya south of the NTP block moisture transport from the Indian Ocean, and the Pamir in the west block moisture transport from the Atlantic Ocean (Tian and others, 2007). During the Indian summer monsoon (ISM), the strong monsoon activity can transport water vapour from the Bay of Bengal to the NTP (Chen and others, 2012). Outside the summer monsoon season, the NTP receives most of its moisture from regional water recycling (Tian and others, 2001).

This paper presents a 58 year atmospheric insoluble dust deposition record (AD 1951-2008) obtained from an ice core drilled at Zangser Kangri (ZK) glacier located on the NTP (Fig. 1). In addition, we investigated the relationships between dust concentration of the ZK ice core and climate variables that impact atmospheric dust loadings on local and regional scales. We also examined the potential teleconnection between atmospheric dust loading at the NTP and the Arctic Oscillation (AO).

\section{DATA AND METHODS \\ Collection of samples}

In April 2009, two ice cores drilled to bedrock (127.7 and $126.7 \mathrm{~m}$ in length for cores 1 and 2, respectively) were retrieved from ZK glacier $\left(34^{\circ} 18^{\prime} \mathrm{N}, 85^{\circ} 51^{\prime} \mathrm{E} ; 6226 \mathrm{~m}\right.$ a.s.l.) located in the interior of the NTP (Fig. 1). The two ice cores were transported frozen to the State Key Laboratory of Cryospheric Sciences (SKLCS, Chinese Academy of Sciences, Lanzhou, China) for processing and analyses. This study is based on the records obtained from core 1 . Core 1 $(\sim 9.4 \mathrm{~cm}$ in diameter) was split axially into two halves. One half was stored for archive; the other was sampled at intervals of $\sim 4-6 \mathrm{~cm}$ in a cold room $\left(\sim-20^{\circ} \mathrm{C}\right)$. A total of 2884 sections were obtained for measurement of stable isotopes, major ions and insoluble particles. The samples for stable oxygen isotopes were cut axially from both sides $(\sim 1 \mathrm{~cm}$ for each side) at each section. In this study, a custom-designed lathe (made from polymethyl methacrylate) was used to decontaminate the ice-core samples. The decontamination procedure was performed in a class 100 laminar flow clean bench located inside a cold room at $-12^{\circ} \mathrm{C}$. Operators wore non-particulating clean suits and low-density polyethylene (LDPE) gloves. The gloves were replaced frequently as 


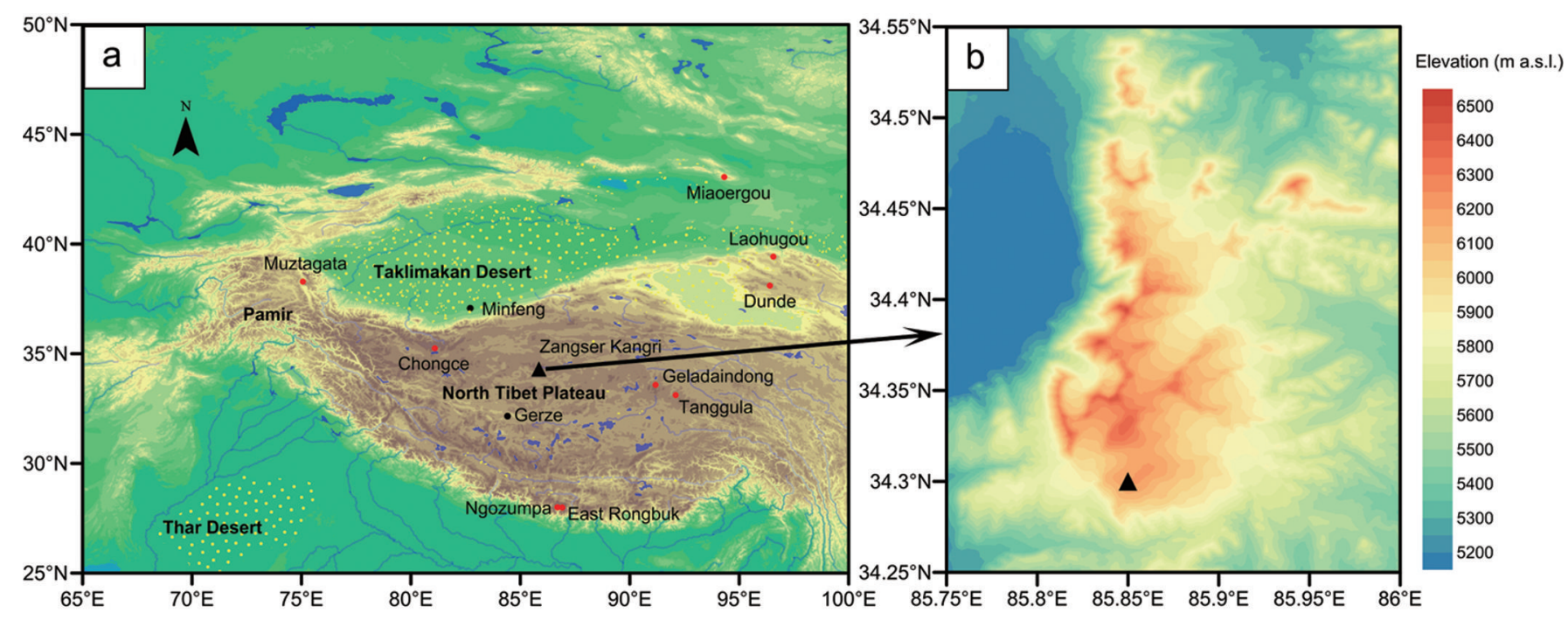

Fig. 1. (a) Map of the study area and (b) location of the ZK ice-core drilling site (black triangle).

needed. Each core was $\sim 5 \mathrm{~cm}$ long and was handled in a series of steps. First, $\sim 5 \mathrm{~mm}$ ice from each end was shaved off with a clean stainless-steel scalpel. The core section was then placed in the lathe and the first $\sim 5 \mathrm{~mm}$ thick veneer layer was shaved off with a clean stainless-steel scalpel. Next, the operator changed LDPE gloves and shaved off a second veneer layer with a new clean stainless-steel scalpel. This procedure was repeated and the third veneer layer was shaved off with a clean ceramic knife. The remaining part of the core section was then held with polypropylene tongs and $\sim 5 \mathrm{~mm}$ ice from each end of the core section was shaved off with a clean ceramic knife. Finally, the remaining inner core section was placed in a clean LDPE bag for microparticle and ion measurement.

\section{Chemical measurements}

The ice-core samples were analyzed for deuterium-hydrogen $(\mathrm{D} / \mathrm{H})$ and oxygen $\left({ }^{18} \mathrm{O} /{ }^{16} \mathrm{O}\right)$ isotope ratios using a Picarro L2120-i Cavity Ring-Down Spectrometer at the Ministry of Education Key Laboratory for Coast and Island Development, Nanjing University. To estimate measurement accuracy and minimize memory effect associated with continuous measurements, the instrument was calibrated on a regular basis against isotopic standards Vienna Standard Mean Ocean Water 2 (VSMOW2), Greenland Ice Sheet Precipitation (GISP) and Standard Light Antarctic Precipitation 2 (SLAP2) provided by the International Atomic Energy Agency. The estimated accuracy was $\pm 0.07 \%$ for oxygen isotope $\left(\delta^{18} \mathrm{O}\right)$ and $\pm 0.23 \%$ ofor deuterium $(\delta \mathrm{D})$. The laboratory working standard was remeasured after every seventh sample. The $\delta^{18} \mathrm{O}$ and $\delta \mathrm{D}$ values were expressed in $\%$ relative to the $\mathrm{VSMOW} 2$ value.

Major cations $\left(\mathrm{Na}^{+}, \mathrm{NH}_{4}^{+}, \mathrm{K}^{+}, \mathrm{Mg}^{2+}\right.$ and $\left.\mathrm{Ca}^{2+}\right)$ and anions $\left(\mathrm{F}^{-}, \mathrm{Cl}^{-}, \mathrm{SO}_{4}{ }^{2-}, \mathrm{NO}_{3}{ }^{-}, \mathrm{C}_{2} \mathrm{O}_{4}{ }^{2-}\right)$ were analyzed using Dionex-600 and ICS-2500 ion chromatographs, respectively. Cations were analyzed using a CS12 $4 \mathrm{~mm}$ column, $200 \mu \mathrm{L}$ loop and isocratic $18 \mathrm{mM}$ methanesulphonic acid (MSA) eluent, and anions with an AS11-HC 4 mm column, $500 \mu \mathrm{L}$ loop and isocratic $25 \mathrm{mM}$ potassium hydroxide $(\mathrm{KOH})$ eluent. Detection limits for measured cations and anions were below $1 \mu \mathrm{g} \mathrm{L}^{-1}$.

Insoluble particles were analyzed using a Coulter Counter Multisizer $3(\mathrm{CCM})$ with an aperture of $50 \mu \mathrm{m}$, set up in a class 100 clean room in the SKLCS. Samples were melted immediately prior to particle analysis. Samples of $2.5 \mathrm{~mL}$ were extracted from the containers using a pipette, and diluted $1: 4$ with $\mathrm{NaCl}$ electrolyte for particle counting. The instrument was set to detect particles with an equivalent spherical diameter larger than $2.0 \mu \mathrm{m}$. Routine analysis of filtered deionized water blanks showed background counts to be on average 10 times lower than in the sample with lowest concentration. Samples were analyzed in random order and in triplicate. Results were then averaged for individual samples, yielding an estimated error of $\leq 10 \%$ on particle number concentrations. The size distribution of dust particles by mass and volume were calculated from the raw count data by assuming spherical particles of uniform density $\rho=2500 \mathrm{~kg} \mathrm{~m}^{-3}$. Mass was derived by integrating the mass size distribution over the measured diameter range and normalizing the result to the sample volume. We also fitted a log-normal distribution to the volume size data for particles with $d$ (diameter) $<30 \mu \mathrm{m}$ to characterize the distribution (Wake and Mayewski, 1994; Steffensen, 1997; Ruth and others, 2003). The density function of the lognormal distribution is given as

$$
\frac{\mathrm{d} V}{\mathrm{~d} \log d}=\frac{V_{\text {total }}}{\sqrt{2 \pi} \log \sigma} \exp \left[-\frac{1}{2}\left(\frac{\log d-\log d_{\mathrm{m}}}{\log \sigma}\right)^{2}\right]
$$

where $V_{\text {total }}$ is the total volume of the log-normal distribution (i.e. integration from $d=0$ to $d=\infty$ ), $d_{\mathrm{m}}$ is the mode of the distribution and $\sigma$ is the log-normal standard deviation. $\sigma$ describes how closely the particle mass is distributed around the mode $d_{\mathrm{m}}$. A total of $68 \%$ of the total log-normal mass is in the size interval $\left[\exp \left(\log d_{\mathrm{m}}-\log \sigma\right) ; \exp \left(\log d_{\mathrm{m}}+\log \sigma\right)\right]$ (logarithm to the base $\mathrm{e}$ is used). For convenience the notation $\mathrm{d} V / \mathrm{d} \log d$ is used instead of $\mathrm{dV} / \mathrm{d} d$.

\section{Dating}

In the NTP, the first-order control on the seasonal $\delta^{18} \mathrm{O}$ variability is temperature (Araguás-Araguás and others, 1998). Low $\delta^{18} \mathrm{O}$ values along the core are associated with winter precipitation and high values with summer precipitation (Tian and others, 2003). Major ions (e.g. $\mathrm{Ca}^{2+}, \mathrm{SO}_{4}{ }^{2-}$ ) in the NTP snow and ice also show clear seasonal cycles, with higher concentrations during winter/spring and lower concentrations during summer (Zhang and others, 2007). 


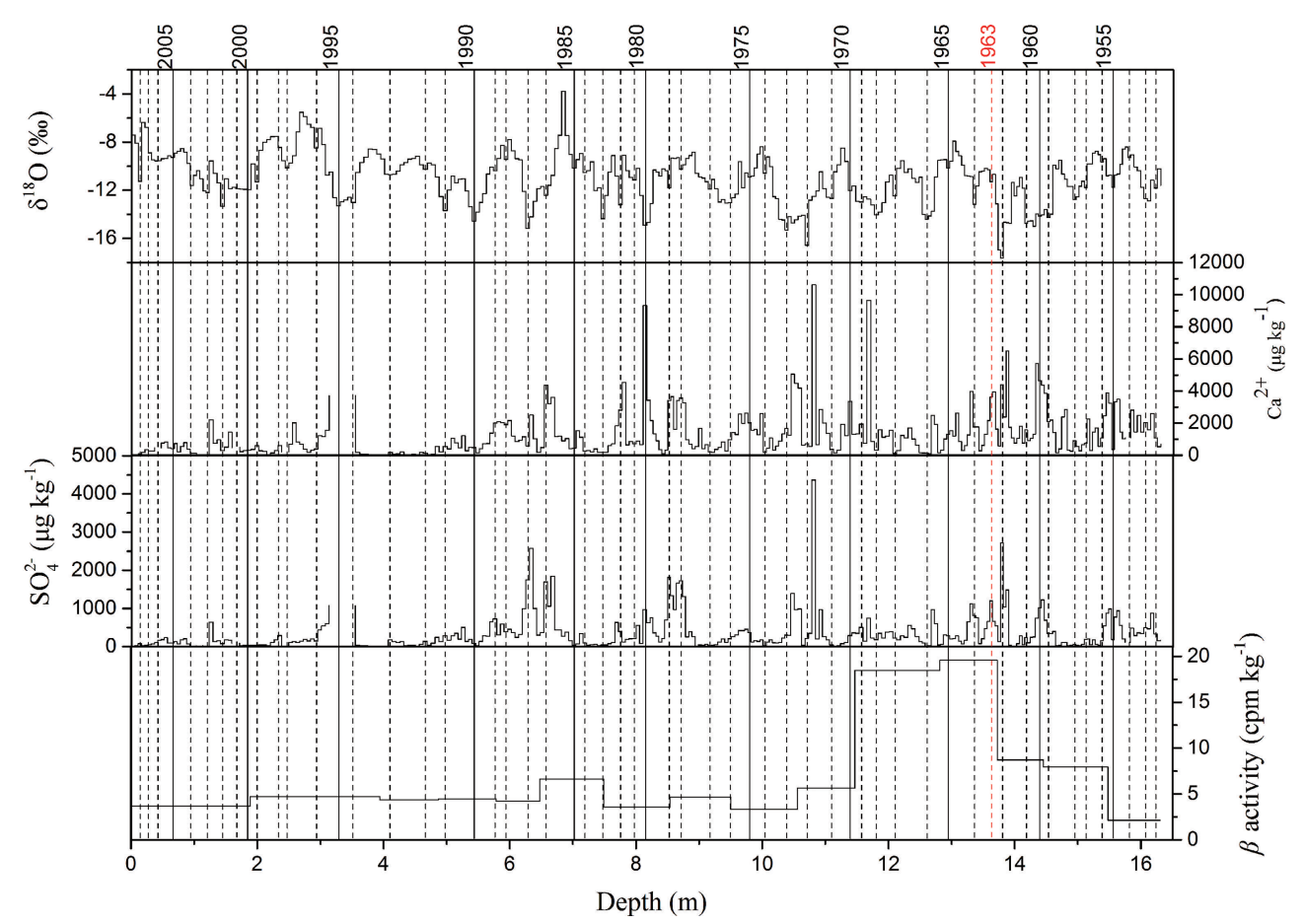

Fig. 2. Dating of the ZK ice core based on the seasonal variation in $\delta^{18} \mathrm{O}, \mathrm{Ca}^{2+}$ and $\mathrm{SO}_{4}{ }^{2-}$. The results were verified by the $\beta$-activity horizons produced by global atmospheric thermonuclear tests in the Northern Hemisphere (AD 1963).

Based on the seasonality of $\delta^{18} \mathrm{O}$ and major ions $\left(\mathrm{Ca}^{2+}\right.$, $\left.\mathrm{SO}_{4}{ }^{2-}\right)$, the $\mathrm{ZK}$ ice core was dated by counting these annual cycles. The dating result was verified by the peak in $\beta$-activity horizon in AD 1963 due to thermonuclear bomb testing (Fig. 2). Core 1 was dated to AD 1951 at $16.38 \mathrm{~m}$ depth (Fig. 2), with an estimated uncertainty of \pm 1 year. The mean annual accumulation rate, calculated from the icecore dating result and density profile (obtained by dividing the mass of each section by volume), is $190 \mathrm{~kg} \mathrm{H}_{2} \mathrm{O} \mathrm{m}^{-2} \mathrm{a}^{-1}$ for the period AD 1951-2008. Although all 2884 samples were analyzed for insoluble particles and major ions, in this paper we focus on the data (308 samples) since AD 1951 because dating below $16.38 \mathrm{~m}$ is not yet available.

\section{RESULTS AND DISCUSSION Dust concentrations}

Figure 3 shows the profiles of dust number $(N)$ and mass $(M)$ concentrations over time. The dust mass concentration ranges from 2558.29 to $5828.65 \mathrm{\mu g} \mathrm{kg}^{-1}$ with a mean value of $3883.00 \mathrm{\mu g} \mathrm{kg}^{-1}$; and the number concentration ranges from 31154 to $63243 \mathrm{~mL}^{-1}$ with a mean value of

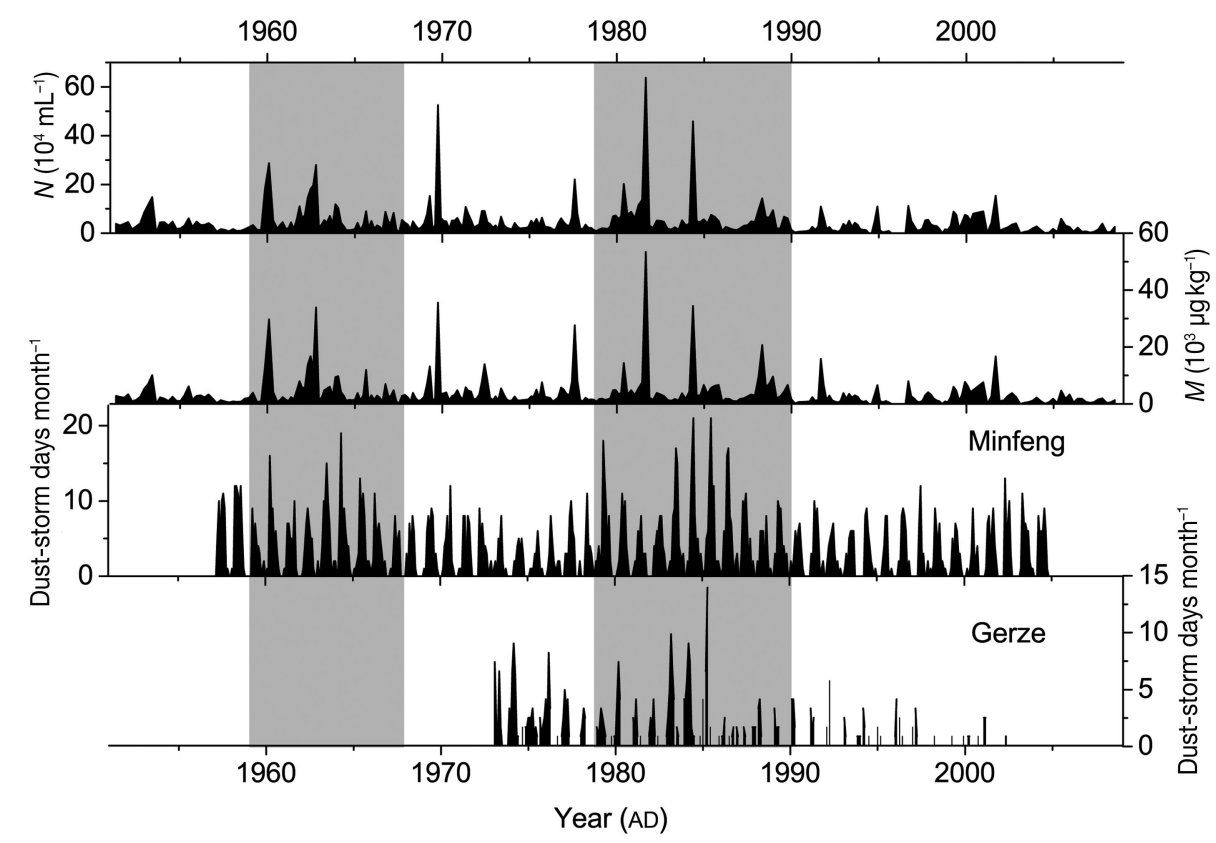

Fig. 3. Profile of dust number $(N)$ and mass $(M)$ in the $Z K$ ice core, and dust-storm variability observed at Minfeng and Gerze stations (Chinese Meteorological Administration). A dust-storm day has strong winds and horizontal visibility $<1 \mathrm{~km}$. 
Table 1. Atmospheric dust concentration in snow and ice at various sites in the Northern Hemisphere

\begin{tabular}{|c|c|c|c|c|c|c|c|c|}
\hline & Latitude & Longitude & $\begin{array}{c}\text { Elevation } \\
\text { ma.s.l. }\end{array}$ & Period & $\begin{array}{c}\text { Size range } \\
\qquad \mu \mathrm{m}\end{array}$ & $\begin{array}{l}\text { Number } \\
10^{3} \mathrm{~mL}^{-1}\end{array}$ & $\begin{array}{c}\text { Mass } \\
\mathrm{ppb}\end{array}$ & Source \\
\hline Zangser Kangri & $34^{\circ} 18^{\prime} \mathrm{N}$ & $85^{\circ} 51^{\prime} \mathrm{E}$ & 6226 & 1951-2008 & $2-30$ & 48.37 & 3883 & This paper \\
\hline Miaoergou & $43^{\circ} 03^{\prime} \mathrm{N}$ & $94^{\circ} 19^{\prime} \mathrm{E}$ & 4518 & 1953-2004 & $2-30$ & 470 & 11900 & Liu and others (2011) \\
\hline Laohugou & $39^{\circ} 15^{\prime} \mathrm{N}$ & $99^{\circ} 20^{\prime} \mathrm{E}$ & 5000 & 2006-12 & $0.57-40$ & 243 & 2876 & Dong and others (2013) \\
\hline Muztagata & $38^{\circ} 17^{\prime} \mathrm{N}$ & $75^{\circ} 00^{\prime} \mathrm{E}$ & 6250 & 1998-2000 & $1-30$ & 268.25 & 8680 & Wu and others (2010) \\
\hline Dunde & $38^{\circ} 06^{\prime} \mathrm{N}$ & $96^{\circ} 24^{\prime} \mathrm{E}$ & 5325 & $1981-86$ & $>2$ & 586.40 & 21007 & Wu and others (2010) \\
\hline Chongce & $35^{\circ} 07^{\prime} \mathrm{N}$ & $81^{\circ} 06^{\prime} \mathrm{E}$ & 6327 & 1980-87 & $>1$ & 616 & 8220 & Wake and Mayewski (1994) \\
\hline Geladaindong & $33^{\circ} 24^{\prime} \mathrm{N}$ & $91^{\circ} 06^{\prime} \mathrm{E}$ & 5950 & 1988-90 & $>1$ & 165.3 & 2630 & Wake and Mayewski (1994) \\
\hline East Rongbuk & $27^{\circ} 59^{\prime} \mathrm{N}$ & $86^{\circ} 55^{\prime} \mathrm{E}$ & 6518 & Last 1400 years & $1-30$ & 8.8 & 466 & $\mathrm{Xu}$ and others (2010) \\
\hline Ngozumpa & $28^{\circ} 00^{\prime} \mathrm{N}$ & $86^{\circ} 42^{\prime} \mathrm{E}$ & 5700 & 1989-90 & $1-13$ & 18.17 & 379 & Wake and Mayewski (1994) \\
\hline Canadian Arctic & $67^{\circ} 15^{\prime} \mathrm{N}$ & $66^{\circ} 45^{\prime} \mathrm{W}$ & 1980 & 1988-94 & $0.65-12$ & 31.6 & 143 & Zdanowicz and others (1998) \\
\hline Penny Ice Cap & & & & & $1-12$ & 13.7 & 129 & \\
\hline Devon Ice Cap & $77^{\circ} \mathrm{N}$ & $82^{\circ} \mathrm{W}$ & 1800 & Last 7000 years & $>1$ & 8.3 & 235 & Fisher and Koerner (1981) \\
\hline Agassiz Ice Cap & $80^{\circ} 42^{\prime} \mathrm{N}$ & $70^{\circ} 06^{\prime} \mathrm{W}$ & 1600 & $\begin{array}{l}1950-77 \\
\text { 1 }\end{array}$ & $>1$ & 18.3 & $\mathrm{n} / \mathrm{a}$ & Koerner and Fisher (1982) \\
\hline & & & & Last 5000 years & $>1$ & 18.2 & $\mathrm{n} / \mathrm{a}$ & \\
\hline Greenland Summit & $72^{\circ} 35^{\prime} \mathrm{N}$ & $37^{\circ} 38^{\prime} \mathrm{W}$ & 3207 & $\begin{array}{l}\text { Snow } \\
\text { LGM* }^{*}\end{array}$ & $\begin{array}{c}0.5-1.2 \\
>2\end{array}$ & $\begin{array}{l}\mathrm{n} / \mathrm{a} \\
\mathrm{n} / \mathrm{a}\end{array}$ & $\begin{array}{r}46 \\
301\end{array}$ & Steffensen (1997) \\
\hline Camp Century & $77^{\circ} 10^{\prime} \mathrm{N}$ & $61^{\circ} 08^{\prime} \mathrm{W}$ & 1885 & Snow & $\begin{array}{c}\mathrm{n} / \mathrm{a} \\
0.02-8\end{array}$ & $\begin{array}{l}n / a \\
n / a\end{array}$ & $\begin{array}{l}35 \\
35\end{array}$ & Murozumi and others (1969) \\
\hline
\end{tabular}

*Last Glacial Maximum.

$48368 \mathrm{~mL}^{-1}$. We compared our results with the dust concentrations from other sites in previous studies (Table 1). Within the NTP, the dust concentrations of various sites showed a clear spatial pattern. The Dunde, Chongce and Muztagata ice cores from the northern margin of the TP had higher dust concentrations, mainly because of their proximity to the major areas of dust emission in Asia (e.g. Taklimakan and Qaidam basin deserts), strong and frequent dust-storm events in northern China, and low precipitation (Wu and others, 2010). The lower dust concentration of the East Rongbuk ice core (located at the southern TP) could be explained by its greater distance from dust source regions. The ZK core was comparable with the Geladaindong ice core, with moderate dust concentration values that lie between the above two groups of sites. The ZK result is an order of magnitude higher than the dust concentrations measured in the southern TP and Greenland (Wake and Mayewski, 1994), again suggesting the influence of distance to dust source on dust concentration records in ice cores. This shows that the variability of dust concentration in the ZK ice core is not only a valuable proxy for reconstructing the history of dust emission in this region, but is also an important indicator for regional atmospheric circulation and dust transport pathways.

\section{Temporal variations and volume-size distribution of dust particles}

The dust number and mass concentrations followed similar temporal variation patterns. They can be divided into five periods based on the 9 year running mean of annual dust mass concentration: three low dust concentration periods (1951-58, 1968-78 and 1990-2008) and two high dust concentration periods (1959-67 and 1979-89) (Fig. 3). The volume-size distribution data from five periods are shown in Figure 4. Each of the five distributions of raw data can be regarded as unimodal. The modes (calculated from the fitted log-normal distributions) range from 4.4 to $5.8 \mu \mathrm{m}$, which are typical of particles deposited in alpine snowfields after a moderate distance of transport (Wake and Mayewski, 1994;
Wu and others, 2010; Dong and others, 2013), but much coarser than those of Himalayan and polar ice cores (Fisher and Koerner, 1981; Zdanowicz and others, 1998; Xu and others, 2007). If the particles with $d>15 \mu \mathrm{m}$ are considered as originating from local sources, their contribution to dust concentration at ZK is $9.7 \%$, lower than the $17.4 \%$ found at the Tanggula ice core $(500 \mathrm{~km}$ southeast of ZK, with a similar natural environment) (Wu and others, 2010), suggesting that the local material contributes less to dust mass at ZK glacier than in the Tanggula Mountains.

\section{Possible dust sources and transport routes}

Periods of high dust concentration recorded in the ZK core corresponded well with periods of peak dust activity at Minfeng and Gerze meteorological stations (Fig. 3). Minfeng station was selected because it had the longest continuous

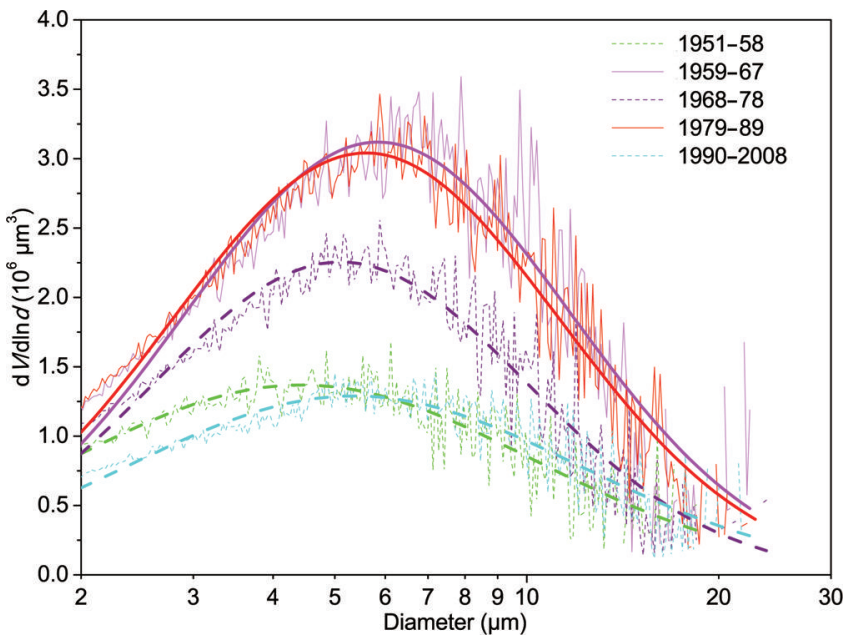

Fig. 4. The volume size distributions of dust particles from five climatic periods. Thin lines represent the original data, whereas thick lines indicate the fitted log-normal distribution density function. Solid lines indicate periods with high dust concentrations, and dashed lines indicate those with low dust concentrations. 


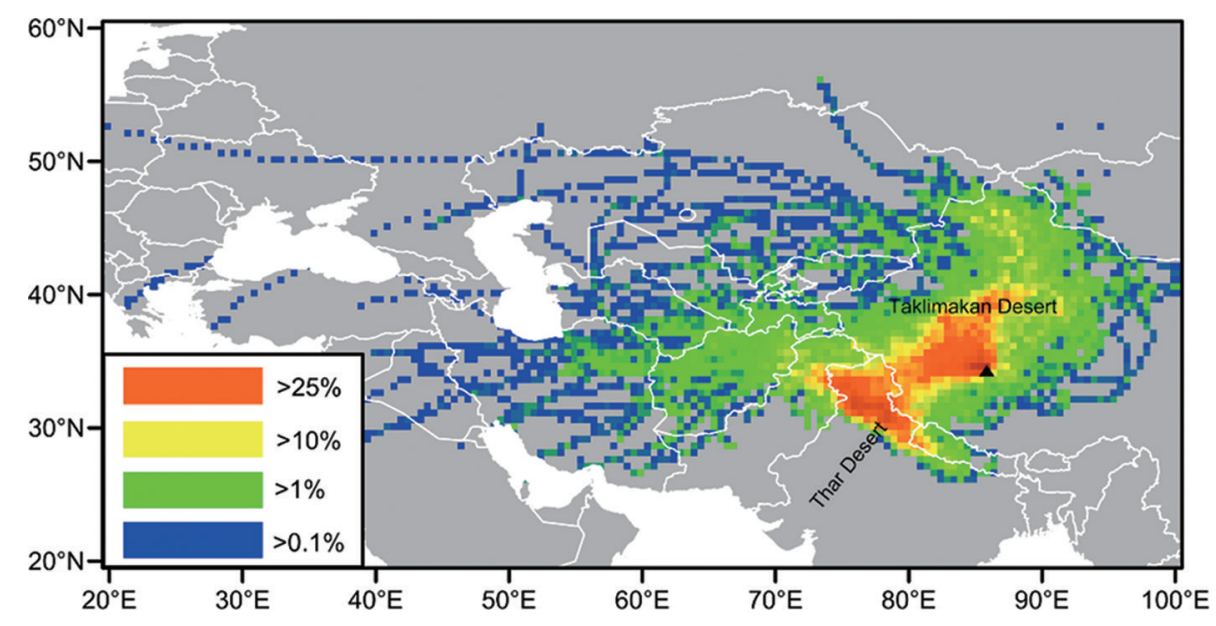

Fig. 5. Frequency plot of 5 day back trajectories during the season of high dust-storm activity (March-May) between 2004 and 2008 . The black triangle indicates the ZK ice-core site. The back trajectory data are from the US National Oceanic and Atmospheric Administration (NOAA) (available at: ftp://arlftp.arlhq.noaa.gov/pub/archives/reanalysis).

record of dust observations (1957-2004) and Gerze station because of its proximity to ZK glacier. Despite some differences between the station dust observations and the ZK dust record, likely owing to differences in local dust sources, elevation and atmospheric dust transport, the similarity between the two, particularly in the 1980s, suggests that the ZK ice-core record could serve as a proxy for regional atmospheric dust loading. This is further confirmed by the correlation analysis of the ZK dust record and station dust data. The mean annual ZK dust record is significantly correlated with the annual station dust-storm records at Minfeng station $(r=0.59, n=48, p<0.01)$ and Gerze station $(r=0.35, n=31, p<0.05)$. The ZK dust record shows stronger correlation with the Minfeng station duststorm data. This may suggest that the Taklimakan desert is the dominant source of dust deposited at ZK glacier during the spring months.

Back-trajectory analysis of air masses provides another method to investigate potential dust-source regions. We used the Hybrid Single-Particle Lagrangian Integrated Trajectory model (HYSPLIT 4.8) (Draxler and Hess, 1998) to investigate the potential transport pathways of the dust particles. Back trajectories were run every 6 hours during

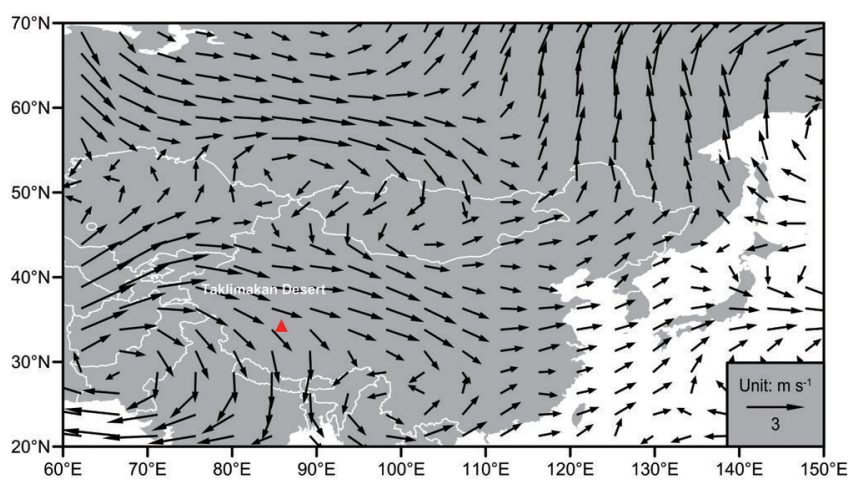

Fig. 6. Composite difference in the spring $500 \mathrm{hPa}$ horizontal wind vectors $\left(\mathrm{m} \mathrm{s}^{-1}\right)$ between years with high and low dust concentrations. $500 \mathrm{hPa}$ wind data are from the US National Centers for Environmental Prediction/US National Center for Atmospheric Research (NCEP/NCAR) re-analysis dataset (available at: www.esrl.noaa.gov/ $\mathrm{psd} / \mathrm{data})$. The red triangle indicates the ZK ice-core site. the high-frequency dust storm season (March-May) between 2004 and 2008 (Fig. 5) (with a total of 1840 trajectories). Back-trajectory frequency analysis suggests that most trajectories to the sampling site originated from the north (e.g. Taklimakan desert) and/or the southwest (e.g. Thar desert). However, it is unlikely that dust generated in the Thar desert could be the source of ZK dust since it is transported eastwards along the southern flank of the Himalaya, which acts as a barrier to dust moving northwards into the inner part of the Tibetan Plateau ( $\mathrm{Wu}$ and others, 2010). Therefore, the Taklimakan desert is most likely the dominant source for ZK dust.

\section{Relationships between dust records and atmospheric circulation}

Previous studies indicated that atmospheric dust loading was closely associated with atmospheric circulations (Westphal and others, 1988; Kang and others, 2003, 2010; Fan and Wang, 2004; Grigholm and others, 2009). We performed a composite analysis of $500 \mathrm{hPa}$ horizontal winds to examine the control of atmospheric circulation on the ZK dust loading. Seven years with extremely high dust concentrations (1959, 1962, 1969, 1977, 1981, 1984 and 1988) and eight years with extremely low dust concentrations (1957, 1991, 1994, 1997, 2003, 2006, 2007 and 2008) during 1951-2008 were selected. Results are presented in Figure 6, which shows the difference of mean spring horizontal winds at $500 \mathrm{hPa}$ between years with higher and lower dust concentration. It is clear that the westerlies over northwestern China and the NTP are stronger during the years of high dust concentration in the ZK core, suggesting that the dust records in the ZK region may be strongly influenced by the westerlies in spring over this region. Grigholm and others (2015) analyzed an ice-core dust record from the southeastern part of the NTP and also concluded that the westerlies are most likely the primary control on dust transport.

\section{Relationships between dust concentration and the AO}

The AO is the most important pattern of climate variability in the middle and high latitudes of the Northern Hemisphere, and explains more of the variance in the extratropical geopotential height anomalies (20-30\%) than any other climate mode (Thompson and Wallace, 1998). The AO is defined by 


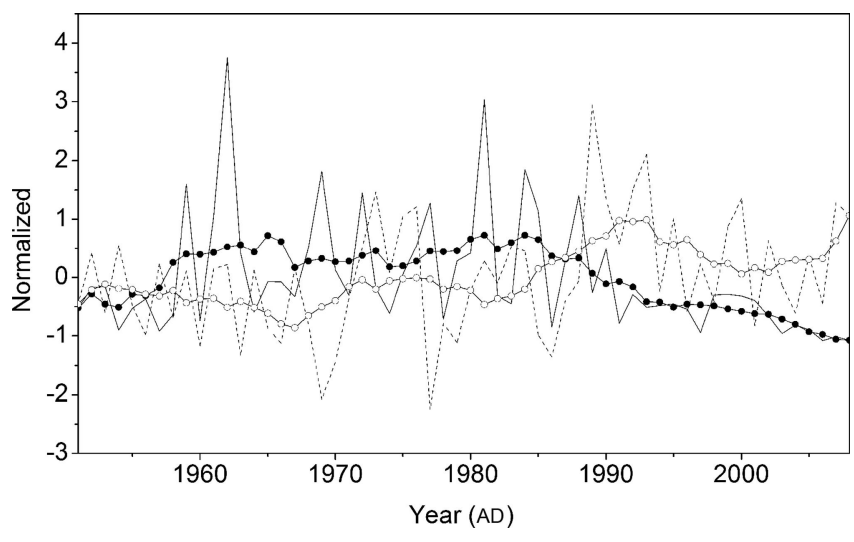

Fig. 7. Normalized time series of the dust concentrations (thin solid line) and the winter $\mathrm{AO}$ index (thin dashed line). The 9 year running mean series are indicated by thick lines with closed and open circles, respectively. The standard $\mathrm{AO}$ index is available at www. cdc.noaa.gov/climateindices/.

the leading empirical orthogonal function of winter sea-level pressure (SLP) fields (Thompson and Wallace, 1998). The westerly winds over the mid-and low latitudes are weaker during winter and spring when the AO index is higher (Thompson and Wallace, 1998; Westphal and others, 1998; Ding and Li, 2005). We examined the association between the annual dust concentrations of the ZK ice core and the winter $\mathrm{AO}$ index, and found a statistically significant negative correlation between the two $(r=-0.35, p=0.01)$ (Fig. 7). Therefore, the winter $\mathrm{AO}$ strength has a moderate influence on the dust concentrations of the ZK ice core at both interdecadal and interannual timescales.

A previous study suggests that higher atmospheric dust loading in the NTP is generally related to cold air outbreaks, the intensity of the westerlies and the intensity of the meridional winds (Kang and others, 2010; Zhang and others, 2015). Therefore, two possible physical mechanisms might explain the influence of the winter $\mathrm{AO}$ on the atmospheric dust loading over the NTP. As illustrated in Figure 8, a strong (weak) anticyclone, corresponding to the positive (negative) phase of winter $\mathrm{AO}$, causes anomalous southerly (northerly) winds over the western part of the Taklimakan desert that tend to weaken (strengthen) the intensity of northwest cold airflow from higher latitudes to the Taklimakan desert. This process appears to be responsible for the springtime decrease (increase) in the frequency of dust storms in the Taklimakan desert during years with the strong (weak) winter AO. Another mechanism is that the winter AO can influence the intensity of the westerlies over mid- and low-latitude Eurasia and thus influence the atmospheric dust loading over the NTP (Han and others, 2008).

\section{CONCLUSIONS}

ZK dust concentration records were used to reconstruct the history of atmospheric dust loading over the NTP during 1951-2008. Our results suggest that the Taklimakan desert is the dominant source of dust deposited at ZK glacier during the spring. Atmospheric dust loading over the NTP exhibits significant decadal changes since 1951, with two periods of high values (1959-67 and 1979-89) and three of low values (1951-58, 1968-78 and 1990-2008). The variability of atmospheric dust loading is most likely controlled by $500 \mathrm{hPa}$ wind speed over the dust source regions. The normalized time series of the winter $\mathrm{AO}$ index shows a significant correlation with the annual dust concentration, implying a possible connection between the winter $\mathrm{AO}$ and the atmospheric dust loading over the NTP.

\section{ACKNOWLEDGEMENTS}

We thank many scientists, technicians, graduate students and porters for their hard work in the field, and Jinzhao Li, Hao Xu, Rong Hua, Chaomin Wang, Boyang Zhao, Yanying Tang, Jing He, Peng Zhou, Yiyun Wang, Zhuocheng Han, Tengjia Han, Xiaofeng Wang and Yanjie Zhao for their help in the laboratory. Meteorological data at Minfeng and Gerze stations were provided by the National Climate Center, Chinese Meteorological Administration. This work was supported by the Natural Science Foundation of China (41330526, 41171052 and 41321062), and the Chinese Academy of Sciences (XDB03030101-4).

\section{REFERENCES}

Araguás-Araguás L, Froehlich K and Rozanski K (1998) Stable isotopic composition of precipitation over southeast Asia. J. Geophys. Res., 103(D22), $28721-28742$ (doi: 10.1029/98JD02582)

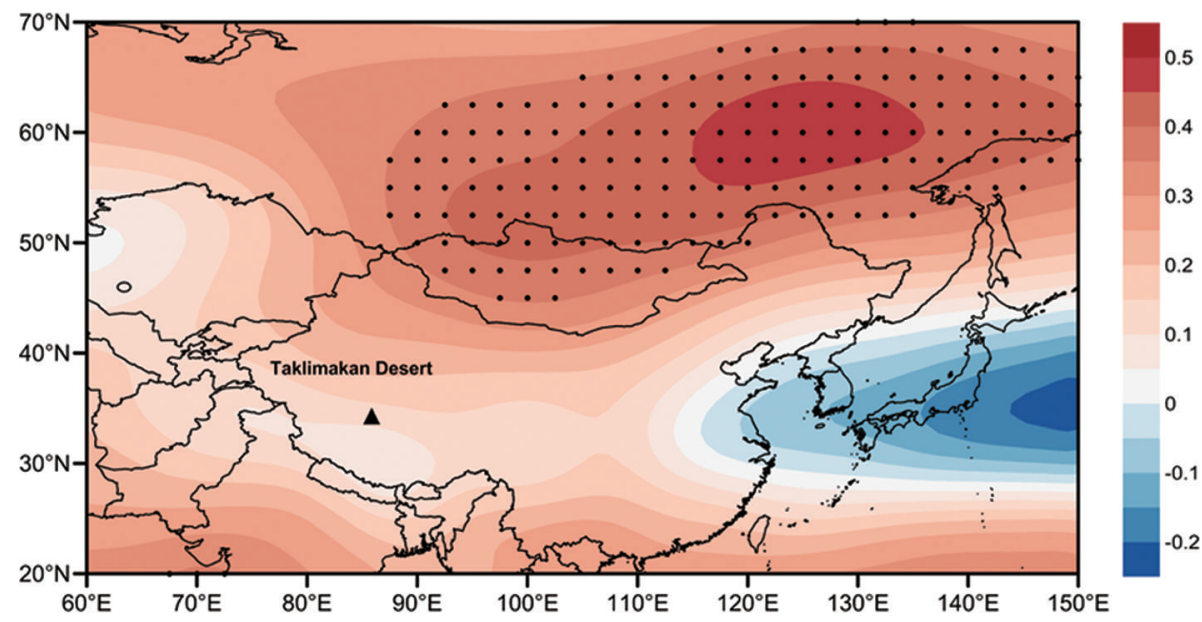

Fig. 8. Correlations between the winter AO index and spring $500 \mathrm{hPa}$ geopotential height for AD 1951-2008. Black dots represent grids where correlation is significant at the $99 \%$ confidence level. The black triangle indicates the ZK ice-core site. 
Chen L, Yi C and Dong G (2012) Discussing sources of moisture feeding the glaciers on the eastern Qangtang Plateau. J. Glaciol. Geocryol., 34(2), 348-356 [in Chinese with English summary]

Ding R and Li J (2005) Decadal change of the spring dust storm in northwest China and the associated atmospheric circulation. Geophys. Res. Lett., 32, L02808 (doi: 10.1029/2004GL021561)

Dong G, Yi C and Chen LJ (2010) An introduction to the physical geography of the Qiangtang Plateau: a frontier for future geoscience research on the Tibetan Plateau. Phys. Geogr., 31(6), 475-492 (doi: 10.2747/0272-3646.31.6.475)

Dong Z and 7 others (2013) Physicochemical characteristics and sources of atmospheric dust deposition in snow packs on the glaciers of western Qilian Mountains, China. Tellus B, 66, 20956 (doi: 10.3402/tellusb.v66.20956)

Draxler RR and Hess GD (1998) An overview of the HYSPLIT_4 modelling system for trajectories. Austral. Meteorol. Mag., 47(4), 295-308

Fan K and Wang H (2004) Antarctic oscillation and the dust weather frequency in North China. Geophys. Res. Lett., 31, L10201 (doi: 10.1029/2004GL019465)

Fisher DA and Koerner RM (1981) Some aspects of climatic change in the High Arctic during the Holocene as deduced from ice cores. W. Maheney, Geol. Abstr., 249-271

Grigholm B and 7 others (2009) Atmospheric soluble dust records from a Tibetan ice core: possible climate proxies and teleconnection with the Pacific Decadal Oscillation. J. Geophys. Res., 114(D20), D20118 (doi: 10.1029/2008JD011242)

Grigholm B and 13 others (2015) Twentieth century dust lows and the weakening of the westerly winds over the Tibetan Plateau. Geophys. Res. Lett., 42(7), 2434-2441 (doi: 10.1002/ 2015GL063217)

Han J, Nakawo M, Goto-Azuma K and Lu C (2006) Impact of finedust air burden on the mass balance of a high mountain glacier: a case study of the Chongce ice cap, west Kunlun Shan, China. Ann. Glaciol., 43, 23-38 (doi: 10.3189/172756406781811907)

Han Y, Fang X, Kang S, Wang H and Kang F (2008) Shifts of dust source regions over central Asia and the Tibetan Plateau: connections with the Arctic oscillation and the westerly jet. Atmos. Environ., 42, 2358-2368 (doi: 10.1016/j.atmosenv. 2007.12.025)

Haywood J and Boucher O (2000) Estimates of the direct and indirect radiative forcing due to tropospheric aerosols: a review. Rev. Geophys., 38(4), 513-543 (doi: 10.1029/1999RG000078)

Kang S, Mayewski PA, Yan Y, Qin D, Yao T and Ren J (2003) Dust records from three ice cores: relationships to spring atmospheric circulation over the Northern Hemisphere. Atmos. Environ., 37, 4823-4835 (doi: 10.1016/j.atmosenv.2003.08.010)

Kang S and 7 others (2010) Variability of atmospheric dust loading over the central Tibetan Plateau based on ice core glaciochemistry. Atmos. Environ., 44(25), 2980-2989 (doi: 10.1016/ j.atmosenv.2010.05.014)

Koerner RM and Fisher D (1982) Acid snow in the Canadian high Arctic. Nature, 295, 137-140 (doi: 10.1038/295137a0)

Liu Y, Hou S, Hong S, Hur SD, Lee K and Wang Y (2011) Highresolution trace element records of an ice core from the eastern Tien Shan, central Asia, since 1953 AD. J. Geophys. Res., 116, D12307 (doi: 10.1029/2010JD015191)

Murozumi M, Chow TJ and Patterson C (1969) Chemical concentrations of pollutant lead aerosols, terrestrial dusts and sea salts in Greenland and Antarctic snow strata. Geochim. Cosmochim. Acta, 33, 1247-1294 (doi: 10.1016/0016-7037 (69)90045-3)

Rosenfeld D and Farbstein H (1992) Possible influence of desert dust on seedability of clouds in Israel. J. Appl. Meteorol., 31(7), 722-731 (doi: 10.1175/1520-0450(1992)031<0722:PIODDO> 2.0.CO;2)

Ruth U, Wagenbach D, Steffensen JP and Bigler M (2003) Continuous record of microparticle concentration and size distribution in the central Greenland NGRIP ice core during the last glacial period. J. Geophys. Res., 108, 4098 (doi: 10.1029/2002JD002376)

Slingo A and 10 others (2006) Observations of the impact of a major Saharan dust storm on the atmospheric radiation balance. Geophys. Res. Lett., 33, L24817 (doi: 10.1029/2006GL027869)

Steffensen JP (1997) The size distribution of microparticles from selected segments of the Greenland Ice Core Project ice core representing different climatic periods. J. Geophys. Res., 102, 26755 (doi: 10.1029/97JC01490)

Thompson DW and Wallace JM (1998) The Arctic Oscillation signature in the wintertime geopotential height and temperature fields. Geophys. Res. Lett., 25(9), 1297-1300 (doi: 10.1029/ 98GL00950)

Thompson LG and 9 others (1997) Tropical climate instability: the last glacial cycle from a Qinghai-Tibetan ice core. Science, 276, 1821-1825 (doi: 10.1126/science.276.5320.1821)

Thompson LG and 7 others (2006) Holocene climate variability archived in the Puruogangri ice cap on the central Tibetan Plateau. Ann. Glaciol., 43, 61-69 (doi: 10.3189/ 172756406781812357)

Tian L, Masson-Delmotte V, Stievenard M, Yao T and Jouzel J (2001) Tibetan Plateau summer monsoon northward extent revealed by measurements of water stable isotopes. J. Geophys. Res., 106, 28 081-28 088 (doi: 10.1029/2001JD900186)

Tian L and 7 others (2003) Oxygen-18 concentrations in recent precipitation and ice cores on the Tibetan Plateau. J. Geophys. Res., 108(D9), 4293 (doi: 10.1029/2002JD002173)

Tian L and 7 others (2007) Stable isotopic variations in west China: a consideration of moisture sources. J. Geophys. Res., 112, D10112 (doi: 10.1029/2006JD007718)

Wake CP and Mayewski PA (1994) Modern eolian dust deposition in central Asia. Tellus B, 46, 220-233 (doi: 10.1034/j.16000889.1994.t01-2-00005.x)

Wang $N$ (2005) Decrease trend of dust event frequency over the past 200 years recorded in the Malan ice core from the northern Tibetan Plateau. Chinese Sci. Bull., 50, 2866-2871 (doi: 10.1360/982005-237)

Westphal DL, Toon OB and Carlson TN (1988) A case study of mobilization and transport of Saharan dust. J. Atmos. Sci., 45, 2145-2175 (doi: 10.1175/1520-0469(1988)045<2145: ACSOMA $>2.0 . C O ; 2)$

Wu G, Yao T, Xu B, Tian L, Zhang C and Zhang X (2010) Dust concentration and flux in ice cores from the Tibetan Plateau over the past few decades. Tellus B, 62(3), 197-206 (doi: 10.1111/j.1600-0889.2010.00457.x)

Wu G and 6 others (2013) Atmospheric dust from a shallow ice core from Tanggula: implications for drought in the central Tibetan Plateau over the past 155 years. Quaternary. Sci. Rev., 59, 57-66 (doi: 10.1016/j.quascirev.2012.10.003)

Xu J, Hou S, Qing D, Kang S, Ren J and Ming J (2007) Dust storm activity over the Tibetan Plateau recorded by a shallow ice core from the north slope of Mt Qomolangma (Everest), Tibet-Himal region. Geophys. Res. Lett., 34, L17504 (doi: 10.1029/ 2007GL030853)

$\mathrm{Xu}$ J and 10 others (2010) A 108.83-m ice-core record of atmospheric dust deposition at Mt Qomolangma (Everest), Central Himalaya. Quat. Res., 73, 33-38 (doi: 10.1016/j.yqres.2009.09.005)

Yumimoto $K$ and 7 others (2010) Summertime trans-Pacific transport of Asian dust. Geophys. Res. Lett., 37, L18815 (doi: 10.1029/2010GL043995)

Zdanowicz CM, Zielinski GA and Wake CP (1998) Characteristics of modern atmospheric dust deposition in snow on the Penny Ice Cap, Baffin Island, Arctic Canada. Tellus B, 50, 506-520 (doi: 10.1034/j.1600-0889.1998.t01-1-00008.x)

Zhang $\mathrm{Y}$ and 11 others (2015) A 500 year atmospheric dust deposition retrieved from a Mt Geladaindong ice core in the central Tibetan Plateau. Atmos. Res., 166, 1-9 (doi: 10.1016/ j.atmosres.2015.06.007) 